\title{
Mental Retardation, X-linked 1
}

National Cancer Institute

\section{Source}

National Cancer Institute. Mental Retardation, X-linked 1. NCI Thesaurus. Code C133729.

An X-linked dominant condition caused by mutation(s) in the IQSEC2 gene, encoding IQ motif and SEC7 domain-containing protein 2 . It is characterized by substantially impaired intellectual functioning and behavioral abnormalities. 